
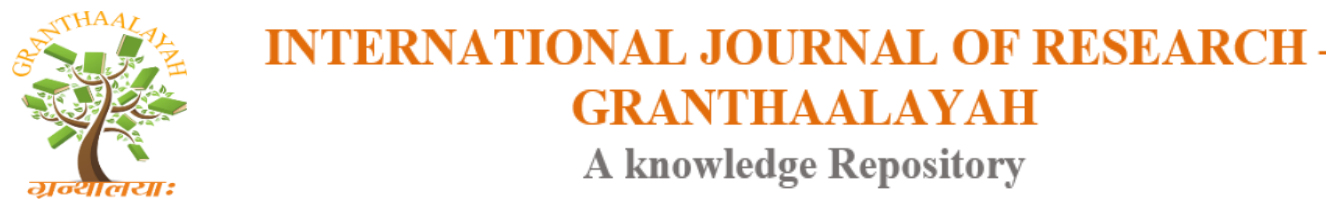

Social

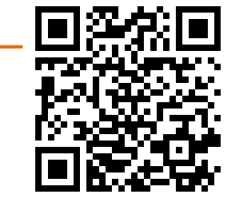

\title{
DEPICTION OF MATERIAL CIRCUMSTANCES OF WOMEN IN JEAN SASSON'S NOVELS
}

\author{
Dr. Vijay Mehta ${ }^{1}$, Ms. Preeti Lahotra ${ }^{2}$ \\ ${ }^{1}$ Professor/ HOD English, Arni University, Indora-HP, India \\ ${ }^{2}$ Research Scholar, Mewar University, Chittorgarh (Raj), India
}

\begin{abstract}
The postmodern American novelist, Jean Sasson, the voice of Islamic women, depicts minutely and graphically the material circumstances of women in her novels. She has presented the material graph of women in the Middle East, escalating to the skyline and the downtrodden life of low pattern of life. The paper specifically explores the material status of women ranging from the Princesses of Saudi Arabia to the level of maids who struggle for existence amidst tortures and variegated stresses. All the women protagonists in her novels continue their struggle with a specific aim of their lives in Islamic pattern of life. Jean Sasson has presented a rich gallery of women portraits in their specific material pattern of life - Princesses, Middle class women struggling to achieve their dreams and lower strata of women.
\end{abstract}

Keywords: Torture; Material Circumstance; Aspirations; Luxurious Patterns.

Cite This Article: Dr. Vijay Mehta, and Ms. Preeti Lahotra. (2019). "DEPICTION OF MATERIAL CIRCUMSTANCES OF WOMEN IN JEAN SASSON'S NOVELS.” International Journal of Research - Granthaalayah, 7(9), 402-414. 10.29121/granthaalayah.v7.i9.2019.626.

\section{Introduction}

\section{Material Circumstances of Women in Jean Sasson's Works}

As a supporter of women, Jean Sasson, in her novels, has presented a rich gallery of women portraits in their specific material pattern of life, varying from royal princesses of Saudi Arabia to maid-servants working in the palatial houses undergoing vicious circles designed by the chauvinistic Muslim society. From a functional viewpoint, social stratification is inevitable in individual differences. As per principles of social stratification, there are three classes in every society- (I) the people with power, prestige, and property (royal class), (II) the people aspiring for power, prestige, and property (middle class) and (III) the people without power, prestige and property (poor class).

A number of earnings and associated consumption patterns often identify the social status of the individuals. The royal people enjoy an affluent life style that combines conspicuous consumption with institutional arrangements that preserve their status. Women of such royal families lead a 
relatively lavish life style, although not all engage in displays of conspicuous consumption on a massive scale. They are free from hardships of routine life. The middle class people struggle and aspire for such a life style which may allow them prestige, power, or property as symbols of social status. The poor, who barely get sufficient or less to support themselves, struggle for their existence and have no such aspirations. Poverty remains a major problem primarily affecting women, children and members of racial and ethnic minority groups.

\section{Women with Power, Prestige, And Property}

\section{Princesses of Royal Families}

Jean Sasson has portrayed the life of Sultana and other princesses of Al Sa'ud family of Saudi Arabia with luxurious patterns of consumption in her Princess trilogy-Princess, Desert royal \& Daughters of Arabia. The writer has delved deep into the interior and biographical details of the princesses of the royals. Their affluent life is narrated through the protagonist Sultana.

Historically, the crude oil made Arabian Peninsula governments extremely rich. This richness grows wildly due to continual oil price rise all over the world. The Saudi kingdom's oil wealth ensured an opulent life style by the privileged class. The representing families of the kingdom wield power, earns royal prestige and a source of endless fascination to the millions below them.

The royal families are known by the status symbols which manifest their position in their respective society. Highly majestic villas, opulent ceremonies and rich celebrations, frequent foreign travels to enjoy holidays, unique collections- jewellery, costumes, luxuries, Mercedes \& Limousines and varied household-a wide range of professionals, including catering, housekeeping, accountancy, secretarial, art curator, world class medical help, expert pilots, etc. all are the consumption patterns which exhibit royal status. Jean Sasson has depicted the royal princessessisters, cousins and friends of Princess, Sultana in her Princess, Desert Royal and Daughters of Arabia. About the tantalizing beauty of Sultana, the royal princess, Jean Sasson exquisitely records her portrait in Desert Royal in the following words:

"However, Sultana was unlike any royal I had met. She was young and beautiful. Her dark hair fell over her shoulders and her eyes sparkled with curiosity. Her lips frequently opened wide in spontaneous laughter. Dressed in expensive clothes and decorated with eye-catching jewels, Sultana captured the undivided attention of everyone around her. "(1) Jean Sasson introduces the reader to the protagonist, Sultana of her Princess trilogy-Princess, Daughters of Arabia and Desert Royal in a graceful manner. Sultana is shown here equal to Juliet or Ophelia or Rosalind of Shakespeare's world.

Sultana's brother, Prince Ali Al Sa'ud's wife, Nada is depicted as royal princess in Daughters of Arabia in the following manner: "Nada swept into the room, her hair fashionably coiffured; she had a haughty expression, and her opulent bosom was crammed into a blinding gold lame dress." (P-290, Desert Royal) In Desert Royal, Jean Sasson portrays another royal princess, cousin of Sultana, Khalidah in the following words:

"She was dressed in a gown covered with tiny pearls, in a shade of green that perfectly set off her chestnut-coloured hair and her amber eyes which were flecked with gold. Her light coloured skin 
was too heavily made up for my liking, but it did nothing to lessen the impact of her lovely features. $"(\mathrm{P}-100$, Desert Royal)

\section{Marriage Celebrations with Royal Show}

Jean Sasson presented a show of royals in Sultana's marriage. In Princess, the princess explains how her elder sister Nura's enormous marble palace was decorated. Hundreds of Filipino, Thai and Yemeni labourers supervised by unsmiling German contractors, had worked around the clock for months to create their monstrosity. The painters, the woodworkers, the metal workers and architects did not speak with one voice; as a result, the palace conflicted within itself. The halls were gilded and richly adorned. About 180 paintings were hanged in the entry hall alone. Garish carpets with embroidered birds and beasts of every type lay across floors.

While Nura had failed miserably in decorating her home, her gardens were a masterpiece. Nearly a mile of lakes and lawns decorated with beautifully arranged flowers, shrubs and trees encircled her palace. There were many surprises to delight the eye: sculptures, colourful bird-houses, fountains spouting water, and even a children's merry-go-round.

Sultana in Princess informs: "I was going to be married to Kareem in the garden at nine o'clock in the evening. Nura knew that I loved yellow roses, and thousands of them, flown in from Europe, were now floating on the lake beside the rose-covered pavilion where Kareem would come to claim me. Nura proudly announced that people already whispering that this was the wedding of the decade." (2)

Further, Sultana tells that her bridal dress was made of the brightest red lace. An expensive wedding dress was offered to her with 'delicate buttons'. Sultana's fiancée, Kareem's 'gift of rubies and diamonds was draped by her sisters around Sultana's neck.' (P-167, Princess)

Jean Sasson has given a vivid and elegant description of Munira's wedding with royal show in Desert Royal. Sultana confesses clearly, "Although Prince Ali possessed no love for his eldest daughter, his position as a high-ranking prince ensured that Munira's wedding would be a grandiose occasion. The celebration and wedding were to take place at the King Faisal Hall, a large building in Riyadh where many Saudi royal wedding have been staged." (P-47, Desert Royal)

Jean Sasson further describes that 'on the night of the wedding, a stream of limousines wove their way to the entrance of the hall, discharging flocks of veiled women. Women were gathering at the King Faisal Hall and the men were congregating at Ali's Riyadh Palace.'(P-47, Desert Royal)

Prince Ali arranged decorators from Egypt. About the royal decorations, Jean Sasson describes in the following lines: "The room was steeped with light, while garish vessels overflowed with goldfoil wrapped candy. Velvet swags with no obvious purpose hung from the ceiling. Great cascades of floral arrangements were suspended from gold-painted columns------Red roses were bunched with yellow daises, while lilac orchids were linked with blue carnations. The garishly decorated platform where Hadi and Munira (Bride and bride-groom) would view, and be viewed by the wedding guests, was covered with blinking green and red lights." (P-49, Desert Royal) 
It was the time when Munira was to make appearance on the stage. All the sisters of Sultana under the command of Nura, the eldest sister gathered on the occasion in a circle. Commenting on the occasion, Sultana says,

"I watched six beautiful dancers advance dramatically through the open doors. The women were trained dancers from Egypt, and were fitted out in elaborate costumes that displayed their voluptuous bodies-------Chanting female drummers, dressed in colourful embroidered dresses, followed the belle dancers--------Twelve tiny girls between the ages of three six followed the drummers. They were the flower girls, and were beautiful dressed in pink satin dresses with matching hair bows and shoes. They scattered petals plucked from purple orchids. These children were members of royal family." (P-52/53, Desert Royal)

\section{Royal Villas of the Princesses}

Jean Sasson depicts opulent villas in her works just to exhibit the royal splendor of princes and princesses living there. In Princess, Sultana gives an exquisite description of her husband, Kareem's opulent villa in Cairo on the banks of the ancient Nile. Jean Sasson depicts the details of the royal villa in the following words:

"The Villa which belonged to Kareem's father had been built in the eighteenth century by a rich Turkish merchant. Restored by Kareem's father to its original splendor, the Villa was laid out in thirty rooms on irregular levels with arched windows leading to the lush garden. The walls were covered with delicate dusty blue tiles with intricate carved creatures in the background." (P-170, Princess)

In Daughters of Arabia, Jean Sasson describes the beauty and elegance of Sultana's palace in Jeddah, a lively port city of Saudi Arabia. In this palace, she depicts the Turkish style of architecture in the following words:

"We entered our large beautiful courtyard that had been designed by a famous Italian fashion designer, and over the years many of our Royal cousins had attempted to unsuccessfully copy the loveliness of this unique 'Turkish' room. The first thing one sees is a flowing waterfall at the back of the room. Clear water falls from it into a large circular pool full of exotic fish. A stone path encircles the pool and beautiful flowers tenderly cared for by our staff of gardeners, line the walkway. There are two raised sitting areas to left and right. Lush green foliage that was imported from Thailand drapes over the Rattan furnishings which are scattered with pastel colored cushions. Glass topped tables are set about in the sitting areas----- a pleasant spot for family to enjoy morning or evening coffee." (3)

There is a detailed description of the Turkish bath: "The Turkish bath house contains four baths, each one set in a different style and size. There are steps that led to each bath, and over one of the larger baths is an arched bridge made of stone. Steam was rising from the water and dissipating in the cool air". (P-166, Daughters of Arabia) Sultana and her daughters always enjoyed wonderful times in the Turkish baths. This Turkish bath lent them always a feeling of scintillating romance in the evening. Such luxuriant and fashionable life-style speaks volumes of truth about royal status of princesses. 
Jean Sasson, in Daughters of Arabia, describes another royal villa which Sultana's brother, Prince Ali, had got built for his favorite wife, Nada. The influence of oil wealth was evident at every turn in the Nada's Villa. Sultana says:

"Conspicuous consumption met my eye as I entered the front hallway laid with white marble that was the width of an airport terminal. The towering staircase gleamed with the glow of silver, and Ali's proud announcement that the columns bracing the structures were coated with real silver. Fifteen foot high doors with solid silver door knobs led into Nada's private living quarters". (P289, Daughters of Arabia)

Further Sultana describes Nada's lavishly furnished bed in the following words:

"The bed was carved solid ivory-Ali had once bragged about the number of elephants that had died to support his bulky frame." (P- 289, Daughters of Arabia)Sultana and her sister Sara were wonderstruck to see the opulent bedroom which Prince Ali had designed for his favorite wife Nada Jean Sasson, in Desert Royal, gives architectural marvels of Paradise Palace built by Sultana's cousins Khalidah and Faddel. This palace was a majestic palace, which was an object of jealousy among other cousins. There was a beautiful winding road leading to an imposing white marble arch, a great Pavilion where a tall handsome Egyptian door man used to open the door of Mercedes and to welcome the guests. Sultana explains the paradise palace:

"The walls were covered in pale yellow silk with a delicate floral design. The carpet featured many lively patterns of exotic flowers and wildly colorful birds. It sank under our feet as we walked. "(P95, Desert Royal)

Sultana explains further the white corridor of the palace. Sultana and her daughters crossed the long corridor into an immense round room. Ornamental columns, lavish furniture, crystal chandeliers and clocks, priceless tapestries, vast mirrors and elegant ceramic panels came together in a stunning overall effect. Jean Sasson here gives a vivid description of the myriads of the palace in following words:

"Several low divans covered in soft colored silks were neatly aligned under arched windows composed of intricate triangles jewel-toned stained glass that depicted scenes of famous Arab warriors in battle. Sparkling clear water flowed from a two-tiered silver-edged fountain. Chinese porcelain vases were centered on tables' polished mahogany inset with mother-of-pearl designs. A blue-tile floor glistened underneath the edges of thick Persian carpets..... a magnificent canopy that appeared to arch into the sky. The ceiling was painted to give the illusion of soft, feathery clouds against a background of the bluest sky." (Page 98, Desert Royal) Surely Faddel had attained his objective of making a paradise. The palace was too perfect, too beautiful. This naturally shows a luxuriant life of people living in these palaces.

\section{Royal Privileges of the Princesses}

As a matter of power and prestige, the royals enjoyed a lot of privileges. The royal people of Saudi Arabia exhibited their influence in their particular circle. For example, when Sultana was to deliver her son Abdullah, a team comprising of a British doctor and four nurses arrived from London. Sultana narrated the affluent behaviour of her husband in the following words, 
"Kareem had awarded the physician with a new Jaguar and 50,000 pounds and his nurses were presented with gold jewellery from the souq along with 5,000 pounds each. The jubilant hospital administrator from Egypt received a substantial contribution to be used for the maternity wing. He was overjoyed with a bonus of three months' salary." (P-199, Princess) Before the delivery Sultana was taken to the hospital in Limousine car to cater her luxury and good health. The use of highly luxurious cars is a status symbol for the royals.

In Daughters of Arabia, there is special clinic for the royal members of Saudi Arabia for the treatment of princesses. Sultana's sister, Reema was getting her treatment in private so that common people could never learn about diseases and ill-health of the royal people. The clinic was often frequented by royal members when confidentiality was desired. It is mentioned that the clinic was acquainted with three princesses who routinely entered the clinic for treatment of alcohol abuse. Sultana informs how royals were always at a distance from the common people:

"Our family escorted inside the building through a little-used door....... The man informed us that an internist, specialist from Beirut, and had recently been hired by the owners of the clinic for care for the members of the royal family." (P-284, Daughters of Arabia)

Saudi Women, in general, are not allowed to travel alone. They can move out only with the appointed guardian, "the mahram". But in Daughters of Arabia, Sultana talks of the privilege of royal princess, when she says, "I could not find the special papers of permission that Kareem kept signed for the women of his family to travel outside the kingdom without the company of the male member of the family." (P-222/23, Daughters of Arabia)

In Desert Royal, there is a mention of huge purchasing power of royal princesses while shopping in New York. Sultana confesses "I was astonished when the manager said that my total expenditure at Bergdorf Goodman's shopping mall amounted to only \$3,88,000." (P-173, Desert Royal) Jean Sasson has elaborately detailed the power and prestige of royal princesses in Princess trilogy.

In Mayada, Daughter of Iraq, Jean Sasson has presented the royal status of women belonging to such families. Mayada's mother, Salwa Al- Husri inherited the royal habits from her grandmother, Melek who was the first cousin of the Sultan of Ottoman Empire. Jean Sasson explains the grace and beauty of Melek in the following word:

"Melek was a famous beauty with skin so white that it was guarded carefully from the rays of the sun and green eyes so brilliant that it was sad they flashed bright lights when she was angry. Melek was so exceedingly wealthy that her riches made her arrogant...... She was known to burn money, because she enjoyed the astonishment on the faces of the observers, and her home was so massive, with more than 70 bedrooms that after her death it was converted into an enormous hotel." (4)

As the only daughter of Melek, Jamila inherited her mother's possessions, which she passed onto her daughters-Salwa, who passed those treasured items onto her own daughters-Mayada and Abdiya. Mayada inherited some valuable heirlooms and still possessed "Decoration of Perfection" presented to Melek by the Ottoman Sultan. This proclamation, consisting of document with the seal of the Sultan, was written in gold and said that on the occasion of Melek's eighteenth birthday 
she would be bestowed with various districts of land. The document came with cash and medal made of diamonds, pearls, rubies, sapphires and emeralds. Mayada had inherited one of the large diamonds and the document, but she was forced to sell the diamond in 1996 when she was living through sanctions in Iraq and desperate to feed her children. But Mayada kept the rare Ottoman document and hoped to pass it on to her own daughter, Fay.

\section{Women Aspiring for Power, Prestige, And Property}

\section{Middle Class Women in Jean Sasson's Works}

Hierarchically middle class people strive to gain position and prestige in the society by virtue of which they can cast their influence. Prestige depends on the respect we earn from the society. Some societies honor the wise and the humble, while the others the boastful and warlike. In modern technological societies, prestige is based largely on occupation and income. The professionals can earn good income and prestige thereby.

Jean Sasson has depicted a large number of women in her novels and works who strive and aspire for prestige, authority and influence. Mayada, daughter of Iraq, is portrayed in the same style. She belongs to the family of the Sultan of Ottoman Empire, but her present position is not out of common. Mayada wishes to lead a respectable life which her mother Salwa Al-Husri once enjoyed. Salwa's grandmother, Melek was the sister of the Sultan of Ottoman Empire. As a middle class woman, she aspires to rise to such a position where she can attain position, prestige and thereby cast influence her unique talents.

Due to her meager economic conditions after her marriage, she had to pursue the profession of journalism.

Mayada's inherited aesthetic sense and excellent communication skills brought her to limelight. Saddam Hussein, then President of Iraq, called upon her to the President House three times and praised her royal inheritance of culture and her writings. The President complimented her, as Mayada records in the following words,

"You are Salwa's daughter. You don't need anything or anyone.....He was giving me a compliment, because my grandfather, Sati had raised his daughter to be a strong woman with opinions......qualities combined in an Arab woman is a rarity in Iraq." (P-151, Mayada, Daughter of Iraq)

There was a photographer in his office to take her snap with the President. Finally Saddam surprised Mayada when he 'kissed her on her forehead and told her to continue making the great Jido Sati Al-Husri proud.' It was final comment from Saddam Hussein:

"Just thinking about your grandfather, Sati-Al-Husri, and what he stood for, makes me proud to be an Arab.” (P-151, Mayada, Daughter of Iraq)

Mayada found her prize in the envelope and "there was exactly 3000 Iraqi dinars. Inside the two leather boxes were two watches. One was an expensive Patek Phillipe with diamonds on white 
gold and the name Saddam written inside the watch, and the second one was the Omega gold watch with Saddam's picture on the face." (P-152, Mayada, Daughter of Iraq)

Second time, she was awarded the prize for she had written an essay for Fonoun magazine titled 'This Beautiful Silence'. Third time in 1983, she wrote

'Vertical Rays of Sun' referring to Sudan's intense heat, and in the article she discussed the country's poverty. Being in that country reminded her how much she loved Iraq. This time, when she visited the President House, she found Saddam Hussein in a very elated mood. The President asked her desires and 'accordingly passed three orders- first, the order for airline tickets for Mayada and her baby to go to meet her mother in London; secondly, the order for the grant of $\$ 16,275$ for the London trip; and thirdly, the order for the allotment of two plots of land in a prime location of Saydiya in Baghdad.' (P-159, Mayada, Daughter of Iraq)

Mayada informs us: "Although my style of writing appealed to Saddam, I knew that my connection to Sati was a major reason. I was so privileged. As I departed the palace, I thought about how the respect and admiration won by my grandfather, Jido Sati, from every Iraqi, including Saddam Hussein, was now affecting my own life in such a positive manner. I thanked my Jido Sati and hoped he heard me.” (P-159, Mayada, Daughter of Iraq)

For middle class people like Mayada, it was a great reward to be photographed with the President of the country and the grant of other material prizes. But Mayada underwent tortures in the Baladiyat prison, cell 52, along with the other shadow women despite the fact that she was given so much respect and recognition by the President of the country.

Jean Sasson describes Mayada Al-Askari in the following words:

"I met an Iraqi woman modestly dressed in an ankle-length garment, her face framed by a black scarf. She was average height and slightly overweight, her face was pale with rosy cheeks, and expectation shown from her light green eyes." (P-17/18, Mayada Daughter of Iraq) She is presented as a common woman of Iraq struggling for existence in a patriarchal society.

Mayada Al-Askari makes mention of about 20 women in cell 52, Baldiyat prison-Samara, Roula, Wafae, Asia, Safna, Ahmed, Rasha, Eman, Sahr Siri, Dr. Sabah. Jean Sasson depicted these portraits of the middle class women who gained respect, prestige and influence in their respective societies but the autocratic regime of Saddam Hussein put them to tortures. These common women were all aspirants of prestige, respect and influence in the society of Iraq, but they were somehow denied by the cruel Iraqi rulers.

In Mayada, Daughter of Iraq, Jean Sasson presents these middle class women with lot of sympathy for one another in the prison. Mayada comments "We are comrades-in-tears." (P-179, Mayada, Daughter of Iraq) The shadow women in cell 52 of Baladiyat prison were all respectable women of middle class families. Jean Sasson describes these women who attained vulnerability but they were charged with false cases and put behind the bars.

Dr Sabah was born in a poor family; father, a simple worker in a cigarette factory on the outskirts of Baghdad and mother, an illiterate housewife. With the gift of intelligence and hard work, she earned Ph.D. degree in engineering. She explains her elevation in the following words: 
"I worked harder than any man at the Ministry of Construction and works. I was told by my supervisor that even Saddam had heard of my determination and skill. In 1979, Saddam sent orders that I was going to be appointed the next Director General of the General Establishment of Constructional projects. I thought my future was made." (P-191, Mayada, Daughter of Iraq)

What an illusion! With embezzlement charge, she was sent to the Baladiyat prison.

Muna is also from a poor family. She was educated in public school and graduated from University at the top of her class. Jean Sasson explains in the following words:

"Muna was married and moved in with her husband in the little house. When investment banks began to open in Iraq, Muna was so smart that she was quickly hired." (P-268, Mayada, Daughter of Iraq)

Safana and her mother lived in the poor area of Habibiya. Her father died during the war with Kuwait, although he was not a soldier.

"Safana was also smart like Muna. She had studied economics and commerce at the University of Baghdad. Safana was lucky to find a full-time job at the same bank where Muna worked. Safana was happy because she would finally have enough money to buy food and medicine for her dear mother, who was by that time an invalid. After work, Safana rushed straight home to attend her mother's needs." (P-269, Mayada, Daughter of Iraq)

"She worked so hard at her new job that she was promoted to department head at the bank, which was a happy, happy day for her" (P-270, Mayada, Daughter of Iraq) But as ill-luck would have been, Munna and Safana, even being good and true, were dragged to Baladiyat prison. All the inmates of the 'cell 52' were good middle class women who could make their life comfortable through dedication, commitment and hard work. They were the source of joy and prosperity in their respective families. But despotic rulers of Iraq victimized the essential goodness of their characters and made them suffer intolerable tortures in Baladiyat prison.

Jean Sasson presents the same middle class women in For the Love of a Son. Maryam, the protagonist of the novel, rebelled against the terrible second class existence that was her destiny as an Afghan woman. She knew what happened to her grandmother, Mayana and her three aunts. The terrible lives of her grandmother and her three aunts made her wish, she was a boy!

As a feisty teenager in Kabul, she was outraged when the Russians invaded her country. She had to flee the country of her choice after she made a public show of defiance. She had a new lease of life in the States where she followed an arranged marriage. But she was always true to the aspirations of her father Ajab. She always loved and respected her father's voice, his conscience and his principles.

Jean Sasson gives us another woman portrait- the portrait of Maryam's mother Sharifa Hassen in the following words: 
"Sharifa Hassen was from a wealthy family held in high regard in Kabul. In fact her father held influence with the Royal family. Her family appeared modern and happy compared with my father's conservative family. She was an unusually ambitious girl. She had been one of the first women to enroll in medical school, although she had switched over to education. After graduation, she postponed marriage to assume a position teaching history and geography at the prestigious Malalai High School built specially for girls." (5)

Maryam's mother was highly fashionable, broad minded, optimistic and highly affectionate lady. She describes her mother, Sharifa in the following words:

"Her desire to emulate Sophia Loren influenced her makeup and dress sense too. Mother claimed that Sophia never appeared in public without full make-up and beautiful clothes so mother was extremely particular and never left home without a light powder on her face, her eye brows fashionably plucked and her lips perfectly lined with her favourite shade of dark pink." (P-60, For the Love of A Son)

Jean Sasson depicts Kurdish middle class women in Love in a Torn Land with regal beauty and core hospitality. In this novel, Joanna's mother Kafia was endowed with exceptional qualities as described in the following passage:

"She was a selfless mother, a devoted wife, a devout Muslim and an accomplished cook. She was so welcoming to visitors that our home was always filled with visiting relatives....... She was a regal beauty. Her skin was fair and her eyes dark and lively.... Even her hands were exquisite, with slender fingers and perfectly palmed nails. It was no surprise to me that she had won her husband's affection, despite the fact their marriage was arranged." (6)

Jean Sasson in 'Love in a Torn Land', portrays middle class Kurdish women as highly hospitable to their guests. Joanna tells about her brother-in-law Hadi's aunty in Kurdistan that the family of Joanna was taken as honoured guests. Hadi's aunty cheerily escorted the guests to the back porch where she pointed out a bucket of fresh spring water, urging them to take a drink, wash and take a seat so that she could serve them food. The aunt told the guests warmly-

"Guests bring good luck with them.... A visitor comes with ten blessings, eats one and leaves nine." (P-47, Love in a Torn Land)

The writer describes Kurdish women in all their bravery and beauty living in a beautiful ambience of Sulaimaniya. Joanna, the protagonist of the novel, is presented as brave, bold and enterprising in taking the decision to be Peshmarga, the Kurdish fighter along with her husband, Sarbast. She exhibits the patriotic zeal as much as Sarbast does.

In Growing Up Bin Laden, Jean Sasson presents Najwa Bin Laden and her wives of Osama Bin Laden as middle class women of the Arabian Society. Najwa presents herself and her background in the following manner:

"My parents and siblings and I lived in a modest villa in the port city of Latakia, Syria. The coastal region of Syria is lively, with sea breezes and fertile land where lucky farmers grow fruits and 
vegetables. Our backyard was abundant with green trees bursting with delicious fruit." (7) All the wives of Osama Bin Laden were friendly to one another, as Najwa narrates, "Over the years the wives of Osama had become uncommonly dear to one another, considering we were married to the same man." (P-91, Growing Up Bin Laden) Further she tells, "Every morning the four wives of my husband would visit each other and chat for a while and then read religious texts." (P-96, Growing Up Bin Laden)

\section{Women Without Power, Prestige and Property}

\section{Women of Lower Strata-Maid Servants}

Poverty stems from a person's location in labour markets and from broad changes in the economic system itself that have reduced the availability of certain types of employment in the specific region. That is, the poor are poor because they compete for jobs in sectors the economy that offers little security and pay very low wages. Most of today's poor are females. Girls and women-teenage mothers, single parents, divorced women of any age and elderly widows- are especially likely to have low incomes and exploitation. Even when they work full-time, and millions do, their wages are minimal and their bare needs are rarely covered in their income groups. Hence they remain standing on the threshold of poverty.

Jean Sasson has depicted a large number of women from the third world countries who somehow reach in Arabian countries to serve as maid servants. Such pretty and young women in the name of maid servants normally become sex slaves and undergo all types of abuses there. In Princess, Jean Sasson describes through Sultana in the following words:

"Since my grandfather's day, we had owned a family of Sudanese slaves. Our slave population increased each when father returned from the Haj with new slave children. Pilgrims from Sudan and Nigeria attending the Haj would sell their children to wealthy Saudis so that they could afford the return journey to their homeland." (P-37, Princess)

Sultana's maid servant, Marci describes the pathetic condition of her friend, Madeline to her princess. Sultana records the poor plight of Marci and Madeline in the following words:

"Marci and Madeline had been childhood friends. As poor as Marci's family was, Madeline's was poorer. Madeline and her seven siblings used to beg on the highway that connected their province to Manila. Occasionally a big car transporting foreigners would stop and huge white hands would drop a few coins into their outstretching palms." (P-123, Princess)

Marci was maid servant to attend Sara and Sultana. Sultana describes the aims and objectives of her maid servant in this uttering: "She wanted to save enough money working as house maid for our family, to return to the Philippines to study nursing. Pilipino nurses are in great demand worldwide and it is considered a lucrative career for women in the Philippines." (P-122, Princess) Marci was allured to Saudi Arabia again to join as a nurse to earn $\$ 1000$ a month whereas she earned \$2000 a month as a maid servant. 
About Madeline, Marci quotes, "Madeline had a dream and a plan to bring that dream to reality. She was a devout Christian, but her confirmation as a maid servant in the Persian Gulf took her to Saudi Arabia." (P-123, Princess) It is highly painful and serious to note what the Saudis think:

"To the head of the household, the secondary status of women indicated in the Quran was understood to be slavery. Any woman who was not a Muslim was considered a prostitute..... Knowing that some of the women of the Orient were for sale convinced the family that all women outside the Muslim faith were for purchase. When a maid was hired, it was assumed she was to be used like an animal, at the whim of the men of the house." (P-137, Princess)

Through the mother of the household, Madeline immediately learned that she was employed 'to serve as sexual release for the two teenage sons' (P-137, Princess). This information without any emotion was sufficient to depress Madeline utterly. Practically as Marci narrated to Sultana, Madeline daily became victim of rape in the family by the head of the household. She could not escape this despairing plight. In the event of escaping the house, she was caught, beaten and kept in the family under guard.

Jean Sasson bewails in Princess how many more Madelines are there, reaching out to uncaring souls and discovering the nothingness that is dressed in the official uniform of those paid to care? Marci gives another account of maid servant, Shakuntale to Sultana in the following passage:

"I heard from Shakuntale from India, who at the age of 13 was sold by her family for a sum of $\$ 170$. She was worked by day and abused by night in much the same manner as the unsuspecting Madeline. But Shakuntale had been bought. She was property that would not be returned..... Shakuntale could never go home again. She was the property of her tormentors." (P-140, Princess) Jean Sasson in Desert Royal brings in the topic of Faddel's harem in which girls from various poor lands were living in a pathetic and agonized predicament. Sultana says, when leaving Paradise Palace of Faddel and Khalidah, "Maha (Sultana's Daughter) became impatient to bring the subject of the young girls in Faddel's harem to my renewed attention." (P-110, Desert Royal) In this context, Sultana remembered an event of 1980, when Cory Aquino, then president of the Philippines, had made a dramatic issue out of young Philipino girls being hired to come as house maids to Saudi Arabia but when they arrived they were forced to serve as sex slaves. Acquino had banned single Philipino woman from travelling to Saudi Arabia.

As a result, the Saudi King Fahd had become furious at this insulting restriction. As such, under pressure, President Acquino failed in his noble effort. Young Pilipino was hired as housemaid. So they serve our men as sex slaves in addition to her household duties. As per Maha's information, Sultana found the heavenly harem of her cousin Faddel in his Paradise Palace and met them personally. Sultana describes the meeting of the girl of the harem in the following words:

"The moment we stepped into the interior of the pavilion, we were surrounded by a large number of excited young women. Most looked Asian..... I looked closely at the young girls. Each one was beautiful, but their tawdry attire drew the eye to more than their beauty. Some were dressed in western style, halter tops and jeans, others wore sheer nighties. There was nothing glamorous about their harem apparels. Sadly, all of them were unbearably young." (P-129, Desert Royal) They were helpless prisoners in the harem. Their pathetic predicament could make any human 
heart melt. One of the younger girls informed Sultana about her helplessness in the following words:

"But ma'am my own parents sold me to this man." (P-130, Desert Royal)

Sultana feels the dismal plight of the girl and bewails there is no legality against the establishment of the harem, when she says; "Dismal thoughts flooded my thinking. Oh, Allah! What a land! What a people... We are so normally corrupt that young women are routinely held captive as sex slaves and incredibly, there are no legal means available for decent people to free these women. Ifelt hot with shame for my country and my countrymen." (P-137, Desert Royal)

\section{References}

[1] Jean Sasson, Desert Royal, (London: Bantam Books, 2000), p.11

[2] Jean Sasson, Princess: A True Story of Life Behind The Veil in Saudi Arabia, (London: Bantam Books, 1993), p. 166.

[3] Jean Sasson, Daughters of Arabia (London: Bantam Books, 1994), p. 14.

[4] Jean Sasson, Mayada, Daughter of Iraq (London: Bantam Books), p. 116/17.

[5] Jean Sasson, For The Love Of A Son, (London: Doubleday, 2010), p. 43.

[6] Jean Sasson, Love in a Torn Land, (London: Bantam Books, 2007), p. 128.

[7] Jean Sasson, Growing up Bin Laden (England: One world Publications, 2010), p.03.

*Corresponding author.

E-mail address: mrvijaymehta@ yahoo.co.in 